\title{
MEMORIAL TO SIR ARNOLD THEILER
}

$\mathrm{S}^{\mathrm{II}}$ $R$ ARNOLD THEILER, founder and first director of the Veterinary Research Institute at Onderstepoort, near Pretoria, South Africa, died in London on July 25, 1936. His great services to veterinary science were widely recognized during his lifetime and many rewards and honours were showered on him. He received no less than seven honorary doctorates. Of other great distinctions may be mentioned his election to the Paris Academy of Sciences, the award of the Laveran Gold Medal, the Budapest Gold Medal, and the Gold Medal of the Royal Agricultural Society of Eng. land. $\mathrm{He}$ was an honorary or corresponding member of some twenty scientific societies.

After his death the country of his adoption bestowed an even greater honour on him than any he had received during his life. The Govern. ment of South Africa decided to erect a monument to his honour at the institute which he had founded

On Wednesday, November 15, 1939, before a large and distinguished gathering, including the members of the Diplomatic Corps, Cabinet Ministers, heads of Government Departments, many scientific workers and other prominent citizens, General the Right Hon. J. C. Smuts,

Prime Minister of the Union of South Africa and a personal friend of Sir Arnold Theiler, unveiled the statue. "To-day," said General Smuts, "is not a day of mourning, it is one of rejoicing. We have come to honour the memory of one of the foremost men in the history of science in South Africa. We are filled with a spirit of rejoicing and appreciation.

"There are some special features about the occasion. Firstly, this is the only occasion on which a monument has been erected to a great man in the Union by the South African Government. Hitherto we have always left it to friends and admirers to collect funds for a memorial, but Sir Arnold seemed to this Government and the previous Government to be an outstanding case where an exception should be made. He had done such great service that we felt we were justified in erecting a memorial on behalf of the entire nation instead of merely of a group."
Secondly, said General Smuts, South Africans had been prone to honour men who had held high public posts in their country - statesmen, soldiers and outstanding public men. Sir Arnold, however, had not been in the public eye, he had not occupied a high position. He had been a man of science pure and simple, and had belonged to a branch of science which had no high honour attached to itveterinary science. "But,", continued General Smuts, "this veterinary doctor made himself, this institute, this country famous all over the world. More than any other man he has put South Africa on the science map of the world."

General Smuts touched on the history of Theiler. He mentioned how General Botha had en couraged the young Swiss veterinarian and how, realizing the vast importance of scientific work, he had sponsored the grant for the erection of the institute at Onderstepoort.

"There are many young men to-day who must have a vivid recollection of Sir Arnold Theiler's great personality. $\mathrm{He}$ was sincere, straight, powerful, enthusiastic, devoted to his work. Many books have been written on his scientific discoveries. There is not an animal disease of any importance which he did not tackle. Every time he found out the cause, the source and nearly always the cure. He worked on such scourges as east coast fever, red-water fever, horse-sickness and blue-tongue. And when we realize how seriously these diseases have retarded our progress in the past, we understand what a benefactor he was.

"It was not hard work alone which took Sir Arnold to the heights; he possessed that added something possessed by so few, 'the genius of insight'. And yet, in spite of his greatness, he was a simple soul; he lived and worked for his profession.

"We should be proud of this institute of Onders. tepoort which he built up," said the Prime Minister. "The men here merely do their jobs. They are not politicians and I hope they never will be. They are here to carry on the scientific tradition of devotion to duty which he began."

The statue, made in granite quarried near Pretoria, was sculptured by Mr. Coert Steynberg. 